\title{
ELITE DIVERSITIES IN PRACTICE: THE CASE OF FREQUENT FLYERS IN THE CZECH REPUBLIC AND SLOVAKIA
}

\author{
Veronika Zuskáčová ${ }^{1}$ (D) Daniel Seidenglanz ${ }^{2}$ (D) \\ ${ }^{1}$ Institute of Geonics \\ of the Czech Academy of Sciences \\ Drobného 28, 60200 Brno: Czech Republic \\ e-mail: veronika.zuskacova@ugn.cas.cz \\ ${ }^{2}$ Department of Geography, Faculty of Science \\ Masaryk University \\ Kotlářská 267/2, 61137 Brno: Czech Republic \\ e-mail: seidenglanz@geogr.muni.cz
}

\begin{abstract}
Due to deregulation of air traffic flying has become increasingly accessible to masses of travellers on the growing low-cost market. Yet, a significant group of passengers seems to remain on the other side - the kinetic elites whose hypermobile lifestyles are performed in privileged spaces. The aim of this paper is to critically address the binary of elite and non-elite passengering and to demonstrate the evidence of a much wider spectrum of individual aeromobile experiences. We use the case study of frequent flyers in the Czech Republic and Slovakia to present the highly diverse practices of passengers usually labelled as elites.
\end{abstract}

\section{Key words}

aeromobile practices $\cdot$ accessibility $\bullet$ frequent flyer $\bullet$ frequent flyer programmes $\bullet$ mobile elite - the Czech Republic • Slovakia

\section{Introduction}

Mobility, whether in spatial or social terms, always represented a crucial stratifying capital in the society dividing people into those who move and those who must wait (Birtchnell \& Caletrío 2014). Although the continual liberalisation of much of the traffic has now brought masses to travel every day, the stratification of today's society according to individual access to different types of mobility did not disappear. Focusing on air transportation we can witness this inequality to exist on various levels. As Cwerner (2009a) writes, the popular "everyone can fly" attitude is still true only for privileged social classes. Similarly, Thurlow and Jaworski (2006) point out, there is no other transport mode that will make the passengers aware of their social status, their class, as much as the airlines do. Standing 
in the long check-in queue while just next to you the privileged others walk down the red carpet towards a smiling airline representative, waiting for ages for a security check and seeing some others running through the fast lanes and electronic gates, having to walk all the way through the luxurious Business class section until you end up at your cramped Economy seat, almost every part of the flying experience is accompanied by the reminder of one's position in the social hierarchy of airline passengers. And for most of the airline passengers this experience includes knowledge that above them are these others, the privileged, the elites.

Despite the stereotypes that are extensively (re)produced by the airliners (Thurlow \& Jaworski 2006), there is, however, not one and uniform world of flying elites, the reality, we believe, may be far more diversified. In our paper, we want to further address the need to recognize and acknowledge the diversity of aeromobile practices and go beyond the simple binary of the elite and non-elite. We thus draw our attention to the group of highly mobile airline passengers, the frequent flyers, that are easily identifiable as they are determined institutionally through their elite membership in various frequent flyer programmes. This decision was inspired by the approach of Gössling and Nilsson (2009), who similarly used the membership in frequent flyer programmes as an indicator of aeromobile lifestyle of passengers at Copenhagen Airport. Unlike them we, however, further use the term frequent flyer to refer solely to the status members of frequent flyer programmes and we excluded entry level members from our analysis intentionally. It means we further pay attention solely to the members who have reached at least the second rank of the membership, often labelled silver or bronze, and naturally all the higher ranks labelled frequently

1 Lucy Budd (2014) and Saulo Cwerner (2009b), however, very accurately demonstrate the existence of the true global aeromobile elites that are far beyond the public sight using private or corporate jets and helicopters to travel between private airports and helipads. gold, diamond or platinum. Some evidence suggests that the majority of elite frequent flyers are business travellers (Thurlow \& Jaworski 2006; Gössling \& Nilsson 2009; Lassen 2009; Kellerman 2012²). Although in our paper we do not purposely limit our focus to business travel, the empirical results that are presented here correspond with the thesis of strong connectedness between frequent flying and business travel.

The aim of this paper is to collect and analyse multisource data that will help us uncover the heterogeneity of mobile practices of frequent flyer business passengers and in so doing to enrich the understanding of highly mobile lifestyles that contribute greatly to the endless intensification of air transportation in Europe. We set our analysis outside the typical Western European regions with the generally high levels of aeromobility ${ }^{3}$ by focusing on the frequent flyers in the Central European, still transforming post-socialist countries of the Czech Republic and Slovakia. This decision was deliberate and reflects many inherent attributes of the area of former Czechoslovakia in connection with air transportation. Despite the fast growth of the air travel industry, the general level of aeromobility is still lower here in comparison with Western Europe (Seidenglanz 2009; Taylor 2016). This is mainly a consequence of the lower supply of air transportation noticeable clearly by the presence of only smaller hubs and rather regional airlines on one side (Burghouwt 2007; Dobruszkes et al. 2011) and the lower demand of passengers for flying on the other. The lower demand can be seen as an evident manifestation of persisting lower regional economic power in absolute and also in relative terms. The lower demand for air transport stems also

\footnotetext{
2 Kellerman (2012) even uses a term frequently flying business persons.

3 In this paper we understand aeromobility as a particular lifestyle choice that involves flying as a prefered mode of long-distance travelling. This approach is inspired mainly by the studies of Gössling and Nilsson (2010) and Higham, Cohen and Cavaliere (2014) who similarly refer to aeromobility in terms of lifestyle and personal choice (and responsibility) that includes frequent or regular flying.
} 
from the modern history of the studied region, it is related namely to the experience of isolation and the absence of possibility to travel freely abroad during the socialist era before 1989. Flying was rather a rare experience for the average inhabitant of Czechoslovakia at that time (Erdösi 2010; Grenčíková 2011; Grenčíková et al. 2011) and is still being seen as an unavailable or even unnecessary mode of transport at least for some socials groups of local population. The current fast development of aeromobility in such environment seems to us, therefore, analytically interesting. With this paper we thus also want to contribute to the understanding of aeromobilities by at least partly specific, Central European perspective, which could enrich the western concepts and thoughts prevailing in this field (Schwanen 2018).

The paper is conducted as a case study which is divided into three mutually interrelated empirical sections ${ }^{4}$. Methodologically, this paper combines quantitative methods in the first two sections with the qualitative approach used in the third section, as we believe it is the mixed methods research design that enables us to study complex issues in the most complex way. In the first section we discuss the long-term development of air transport accessibility in the Czech Republic and Slovakia and drawing from the current flight supply data we analyse the connectivity of airports available to frequent flyers in the targeted area (firstly hub airports in Prague, Vienna and Warsaw ${ }^{5}$ and secondly

4 The communication partners and largely the spatiality of their aeromobile practices is the aspect which interconnects all empirical sections into one interrelated unit and, moreover, this is the key to the spatial focus of the whole paper. Selection of analysed Central and Western European airports as well as of frequent flyer loyalty programmes including their entry points in respective sections of this paper is given by the fact they are used by the interviewees from the last, qualitative section of the paper.

5 Clearly, Vienna and Warsaw are located outside the geographic area of the Czech Republic and Slovakia, however, they are commonly used by residents of some parts of these two countries as their "home" hub airports or as home airports of their favourite network airlines respectively. smaller airports in Brno, Ostrava, Košice, Bratislava and Poprad/Tatry). The flight supply in Prague, Vienna and Warsaw is compared to selected primary hubs in Western Europe (Frankfurt and Amsterdam) as we try to demonstrate the existence of regional barrier in the air transport availability which modifies the aeromobile practices and strategies of the Czech and Slovak frequent flyers. The data used in this part originates from the OAG Aviation and the Flightstats datasets.

The second section is devoted to the analysis of main frequent flyer programmes offered by three principal airline alliances to all its passengers, within them, of course, to Czech and Slovak frequent flyers. The programmes analysed empirically in this section are Miles and More of Star Alliance available to Czech and Slovak travellers primarily via hubs in Vienna (Austrian Airlines), Warsaw (LOT) and Frankfurt and Munich (Lufthansa), Flying Blue of Sky Team alliance available via Amsterdam (KLM) and Prague (Czech Airlines) and Executive Club of Oneworld alliance accessible in a most comfortable way via London (British Airways). We are looking closer mainly at the internal hierarchy of its members and the benefits they offer, and we interpret these differences as an important source of the distinctions in the practices of Czech and Slovak airline passengers. Frequent flyer programmes are thus considered in our view as a source of passengers sorting that often creates segregated sub-groups of frequent flyers.

Lastly, we focus on the lived aeromobile practices of frequent flyers to examine their internal diversity in a more detail. For this purpose, we have analysed five semi-structured interviews with frequent flyers from the Czech Republic and Slovakia, that served as pilot interviews for another project of one of the authors. The interviewees were approached by the authors using references from mutual acquaintances taking three main criteria into account - the minimum of 40 individual flights taken in the past 12 months, at least a 2 nd rank frequent flyer programme membership and a usual residence in the Czech 
Republic or Slovakia. All interviews have been collected from March till July of 2016. During the interviews, all frequent flyers were asked to describe the network of places they have visited by air in the past year and to reconstruct their last journey in the free narrative form. We have than approached the collected data set using the Atlas.ti software with the two research questions in mind, namely asking: What practices do local frequent flyers employ to cope with the airport accessibility in their region, and if their frequent flyer status affects the spatiality of their journeys and how? We need to stress at this point that the qualitative analysis of interviews is meant to draw on the issues of airport accessibility and spatial strategies of frequent flyers in a vivid form of the firsthand experiences rather than to generalize its conclusions to the wide group of all Czech and Slovak frequent flyers.

\section{Air transport accessibility and the patterns of the aeromobile strategies}

The development of air transport supply and demand and simultaneously of its spatial and social accessibility has been very dynamic in the last few decades. The gradual deregulation of the industry, continuing globalization of economy, life-style changes and increasing wealth which enhanced the possibility to spend growing parts of income on traveling and tourism are some of the examples of highly influential factors beyond that advance (Bowen 2010; Rodrigue et al. 2017). If we compare the total amount of offered flights in Europe and their spatial distribution in 1980s or 1990s and now, we can undoubtedly conclude the sheer increase of scheduled flights on one side and their spatial de-concentration on the other. During the given period, many smaller airports were successively integrated into the regular airline networks. The progress of this phenomenon is illustrated in Figure 1 showing principal air routes ${ }^{6}$ starting in the area of four postsocialist countries in Central Europe including the Czech Republic, Slovakia, Poland and Hungary. While 200 of these regular routes started only in four airports in the targeted area (in Prague, Warsaw, Budapest and Bratislava) and terminated in limited number of destinations in 1990, there were almost 500 routes from 15 airports approximately 20 years later. Daily flights were gradually introduced also to the secondary cities in the given region such as to Kraków, Gdańsk, Wrocław, Brno, Ostrava and Košice. Moreover, the total seat capacity on all scheduled flights has more than quadrupled within the period of 20 years.

\footnotetext{
6 Principal air routes are routes where the offered seat capacity exceeds the level of 5,000 seats per one month for the purposes of this analysis. It means that this type of route is served at least daily with a plane with 160 or 170 seats on board in average.
}

Cities are indicated by following numbers in the Figure 1:
1. Amsterdam
16. Dublin
2. Athens
17. Düsseldorf
3. Barcelona
18. East Midlands
4. Berlin
19. Ekaterinburg (Yekaterinburg)
5. Birmingham
20. Frankfurt
6. Bratislava
21. Gdańsk
7. Brno
22. Geneva
8. Brussels
23. Helsinki
9. Budapest
24. Heraklion (Iraklion)
10. Bucharest
25. Istanbul
11. Bydgoszcz
26. Katowice
12. Cologne/Bonn
27. Kiev
28. Košice
14. Cracow (Kraków)
29. Larnaca
15. Dortmund
31. Łódź
32. London
33. Madrid
34. Milano
35. Moscow
36. Munich
37. Oslo
38. Ostrava
39. Paris
40. Poznań
41. Prague
42. Riga
43. Rome
44. Rzeszów
45. Sofia
46. Stockholm
47. Stuttgart
48. Tel Aviv
49. Thessalonika
50. Tirana
51. Vienna
52. Vilnius
53. Warsaw
54. Wrocław
55. Zürich
56. New York
57. Toronto
58. Chicago
59. Seoul 

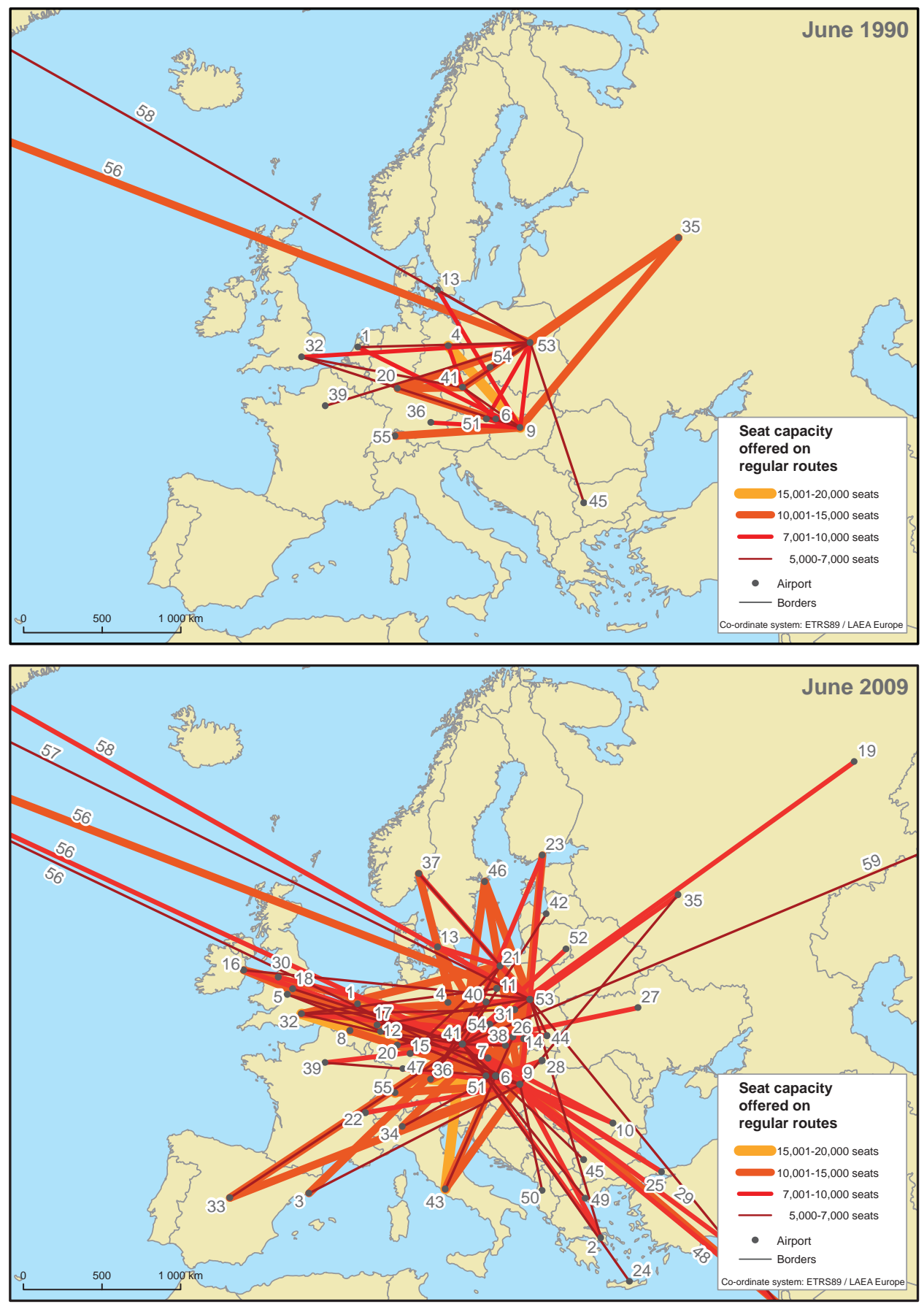

Figure 1. The development of principal air routes starting in the Czech Republic, Slovakia, Poland and Hungary between June 1990 and June 2009

Note: Principal air routes are routes where the offered seat capacity exceeds the level of 5,000 seats per one month at least in one direction.

Source: Based on OAG Aviation database. 
Although the evidence of continuing spatial expansion of air services seems to support the assumption of general or universal air transport accessibility in the contemporary Europe in the sense of its accessibility to (almost) all people (almost) everywhere (Cwerner 2009; Urry 2009) and on flying as a standard, normal or even unavoidable means of passenger transport (Adey et al. 2007), the truth is much more complex. In the more focused view, we argue, the air transport accessibility, despite its continuing improvement, is by all means not uniform or homogeneous in space. This claim is valid also in the European space where the air transport accessibility is rather strongly diversified based on the position of individual airports within the airline networks and the airport hierarchy.

Accordingly, the Czech Republic and Slovakia are, unlike the Western European countries, served primarily via smaller and less prominent hubs in Prague, Warsaw and Vienna (Grenčíková et al. 2011; Kraft \& Havlíková 2016; Taylor 2016). Table 1 shows significant differences in the number of departing flights from these three airports in comparison with the two selected hubs in Western Europe during a week in October 2017. The general level of air traffic supply is approximately three times higher in Frankfurt and Amsterdam than in Prague, Warsaw and Vienna, and further sharp distinction is visible on the number of direct intercontinental flights. For illustration, there are only 9 flights weekly from Prague to North America in comparison with 353 flights from Frankfurt. Latin America and the Caribbean are even completely inaccessible from Prague, Warsaw or Vienna by direct flights. The evidence of this uneven provision of air transport accessibility has been recently commented by several studies in transport geography using traffic and network data of various types (carried passengers, operated

Table 1. Hubs/main airports: flights during a week in October 2017 (2nd - 8th October)

\begin{tabular}{|l|r|r|r|r|r|}
\hline \multirow{2}{*}{} & \multicolumn{3}{|c|}{$\begin{array}{c}\text { Hubs/main airports serving Czech } \\
\text { and Slovak interview partners }\end{array}$} & $\begin{array}{c}\text { Selected European hubs/ } \\
\text { main airports }\end{array}$ \\
\cline { 2 - 6 } & $\begin{array}{c}\text { Vienna } \\
\text { (VIE) }\end{array}$ & $\begin{array}{c}\text { Prague } \\
\text { (PRG) }\end{array}$ & $\begin{array}{c}\text { Warsaw } \\
\text { (WAW) }\end{array}$ & $\begin{array}{c}\text { Frankfurt } \\
\text { (FRA) }\end{array}$ & $\begin{array}{c}\text { Amsterdam } \\
\text { (AMS) }\end{array}$ \\
\hline Total number of flights & 2,290 & 1,287 & 1,581 & 4,714 & 4,799 \\
\hline Flights to Europe & 2,018 & 1,137 & 1,438 & 3,548 & 3,938 \\
\hline - London (LHR, LGW, LCY, LTN, STN) & 86 & 78 & 58 & 173 & 374 \\
- Paris (CDG, ORY) & 57 & 62 & 48 & 96 & 95 \\
- Frankfurt (FRA) & 89 & 47 & 49 & & 83 \\
\hline Flights to North America & 37 & 9 & 38 & 353 & 288 \\
\hline - New York (JFK, LGA, EWR) & 11 & 5 & 14 & 45 & 41 \\
- Chicago (ORD) & 6 & 0 & 11 & 28 & 14 \\
- Atlanta (ATL) & 0 & 0 & 0 & 14 & 28 \\
\hline Flights to Asia & 211 & 113 & 96 & 585 & 363 \\
\hline - Beijing (PEK) & 9 & 3 & 7 & 21 & 14 \\
- Dubai (DXB) & 14 & 16 & 7 & 28 & 23 \\
\hline - Tokyo (NRT, HND) & 0 & 0 & 4 & 28 & 7 \\
\hline Flights to Africa & 25 & 28 & 9 & 157 & 112 \\
Flights to Latin America and the Caribbean & 0 & 0 & 0 & 71 & 100 \\
\hline
\end{tabular}

Source: Based on flightstats.com. 
flights, seat capacities, direct and indirect connectivity, networkability etc., see Burghouwt 2007; Dobruszkes et al. 2011; Derudder et al. 2010; Lee 2009 and many others), however, unlike them we connect this fact newly with travelling behaviour of frequent flyers. We suppose these differences significantly affect their aeromobile practices, strategies, habits and routines because requirements of the world travellers can be hardly fulfilled smoothly by smaller hubs. The lower supply in the hubs that serve the Czech Republic and Slovakia of both flights in total and intercontinental flights in particular can, therefore, be a complication for frequent flyers residing in their vicinity as they inevitably have to undergo more indirect flights, fly longer, use more detour routes, or even travel further by surface transport modes to reach larger hub or modify their mobile behaviour in a different way. As a consequence, less prominent airports create a sort of a spatial and temporal barrier contributing to the lengthening of the journeys of Czech and Slovak frequent flyers in comparison with their western counterparts. Access to the air transport supporting infrastructures of various hierarchical or traffic levels, therefore, enrich the internal differentiation of the group of frequent flyers significantly (Cresswell 2006).

Beside the national hub in Prague, in the Czech Republic and Slovakia there are now several smaller airports in Brno, Košice, Bratislava, Ostrava and Poprad/Tatry with regular direct flight services, see Table 2 for more details. They are, however, integrated into the air transport system less intensively, only as spokes or end points in the airline networks. They are served either by feeder flights of network airlines from and to their respective hubs (e.g. flights from Košice to Vienna, Prague and Warsaw or from Ostrava to Prague) or by flights of low-cost carriers (e.g. flights from all airports to London Luton or London Stansted). The introduction of regular air services into selected secondary or even tertiary Czech and Slovak cities improved air transport accessibility in space, nevertheless, in a rather particular way because the total supply of flights in these airports is generally low. The busiest from these regional point airports, the Bratislava airport, handles only 100 scheduled flights a week, which is more than 12 times less than the national hub in Prague. Moreover, in the overview of destinations in Table 2 we can often find cities that are primarily business destinations of knowledge industries (London, Cologne, Munich, Brussels, Milan, Dubai). The long-term existence of regular flights to regional business centres indicates a vivid corporate mobility mostly within the IT sector. As a consequence, next to the group of true world travellers noted above another type of frequent flyers is to be expected to occur on these regional routes - the commuters. This specific sort of frequent flyers, on contrary, highly profits from the extended network of regional airports as they travel frequently between the place of their residence and their offices abroad (Salt 2010; Wickham \& Vecchi 2010). With the newly introduced flights the regular commuting in a week, biweek or month regime is suddenly available and easily affordable even in remote regions of the Czech Republic and Slovakia. The emergence of regular plane commuters also in smaller Czech and Slovak cities heterogenizes the elite highly mobile groups by the local presence of passengers with specific flying and spatial practices that are examined in section 3 of this paper in a more detail.

\section{Frequent flyers loyalty programmes}

The frequent flyer loyalty programmes are schemes that aim to bind the customers to a particular carrier or an alliance of airlines and thus to encourage their loyal behaviour. There are around 110 different frequent flyer programmes worldwide with some 160 million people around the world collecting bonus points (Gössling \& Nilsson 2009). When the customers reach a certain amount of tier points they are assigned an elite status granting them access to additional services, treats and privileges such as access to 
Table 2. Regional point airports: flights during a week in October 2017 (2nd-8th October)

\begin{tabular}{|c|c|c|c|c|c|}
\hline & \multicolumn{5}{|c|}{ Regional point airports in the Czech Republic and Slovakia } \\
\hline & \multicolumn{2}{|c|}{ serving interview partners } & \multicolumn{3}{|c|}{ other } \\
\hline & $\begin{array}{c}\text { Brno } \\
\text { (BRQ) }\end{array}$ & $\begin{array}{l}\text { Košice } \\
\text { (KSC) }\end{array}$ & $\begin{array}{c}\text { Bratislava } \\
\text { (BTS) }\end{array}$ & $\begin{array}{c}\text { Poprad/Tatry } \\
\text { (TAT) }\end{array}$ & $\begin{array}{c}\text { Ostrava } \\
\text { (OSR) }\end{array}$ \\
\hline Total number of flights & 27 & 56 & 100 & 3 & 12 \\
\hline Flights to Europe & 27 & 54 & 95 & 3 & 11 \\
\hline European destinations & $\begin{array}{l}\text { 10x London } \\
\text { (7x Stansted + } \\
3 x \text { Luton), } \\
\text { 12x Munich, } \\
2 x \text { Eindhoven }\end{array}$ & $\begin{array}{l}\text { 11x Vienna, } \\
\text { 13x Prague, } \\
8 x \text { Warsaw, } \\
\text { 7x London } \\
\text { Luton, } \\
6 x \text { Bratislava, } \\
4 x \text { Istanbul, } \\
\text { 3x Doncaster, } \\
\text { 2x Munich }\end{array}$ & $\begin{array}{l}\text { 11x London } \\
\text { Stansted, 7x Du- } \\
\text { blin, 6x Prague, } \\
\text { 6x Košice, } \\
\text { 4x Warsaw, 4x } \\
\text { Kiev, 4x Berlin, } \\
\text { 4x Brussels } \\
\text { Charleroi, } \\
\text { 4x Milan Berga- } \\
\text { mo, 4x Moscow } \\
\text { Vnukovo, } \\
\text { 4x Skopje, } \\
\text { 3x Manchester, } \\
\text { 3x Rome Ciam- } \\
\text { pino, 3x Sofia, } \\
\text { 3x Birmingham, } \\
\text { 2x Athens, } \\
\text { 2x Barcelona } \\
\text { Girona, 2x Edin- } \\
\text { burgh, 2x Cluj- } \\
\text { Napoca, 2x } \\
\text { Leeds Bradford, } \\
\text { 2x Madrid, 2x } \\
\text { Nis, 2x Alghero, } \\
\text { 2x Malaga, 2x } \\
\text { Paris Beauvais, } \\
\text { 2x Trapani, } \\
\text { 2x Tuzla, 1x } \\
\text { leraklio }\end{array}$ & $\begin{array}{l}\text { 3x London } \\
\text { Luton }\end{array}$ & $\begin{array}{l}\text { 6x Prague, } \\
3 x \text { London } \\
\text { Stansted, } \\
\text { 2x Milan } \\
\text { Bergamo }\end{array}$ \\
\hline Flights outside Europe & 0 & 2 & 5 & 0 & 1 \\
\hline Non-European destinations & . & $2 x$ Tel Aviv & $\begin{array}{l}\text { 3x Dubai, } \\
2 x \text { Tel Aviv }\end{array}$ & . & 1x Dubai \\
\hline
\end{tabular}

Source: Based on flightstats.com.

airport lounges and fast tracks, free upgrades to business class, additional baggage allowance, priority boarding and many more. The programmes often further hierarchize its members to several elite ranks according to the number of collected tier points that correspond with the amount of time and money they spend on their flights. Thurlow and Jaworski (2006) interestingly point out that behind the success of frequent flyer programmes are not the material benefits of the high-rank membership but the ostentatious declaration of the elite social status.

In this section we examine various procedures of passengers sorting on the example of three distinct frequent flyer programmes commonly used by passengers from the Czech Republic and Slovakia - the Miles and More (Tab. 3), Flying Blue (Tab. 4) and Executive Club programmes (Tab. 5). Moreover, we consider these programmes to be the stimuli for different spatial strategies and 
Table 3. Miles and More: selected principles of FF programme as a way to diversify travel experience

\begin{tabular}{|c|c|c|c|c|}
\hline & & \multicolumn{3}{|c|}{ Frequent flyer levels } \\
\hline & & frequent traveller & senator & HON Circle member \\
\hline \multirow{2}{*}{\multicolumn{2}{|c|}{ How to qualify }} & $\begin{array}{l}35,000 \text { status miles } \\
\text { or } 30 \text { flights }\end{array}$ & 100,000 status miles & $\begin{array}{l}600,000 \text { HON Circle miles } \\
\text { in } 2 \text { calendar years }\end{array}$ \\
\hline & & \multicolumn{3}{|c|}{$\begin{array}{l}\text { status miles are earned on scheduled flights, HON Circle miles are earned } \\
\text { on scheduled flights when flying first or business class (e.g. flight Prague } \\
\text { - Vienna in Economy lowest class earns } 125 \text { status miles, flight Vienna - Tokyo } \\
\text { in Economy lowest class earns } 1421 \text { status miles, in Business lowest class } \\
5685 \text { status miles) }\end{array}$} \\
\hline \multirow{7}{*}{ 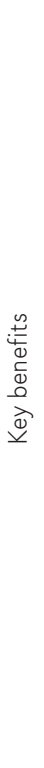 } & fly one class higher & no & 2 eVouchers & 6 eVouchers \\
\hline & preferential check-in & business class check-in & $\begin{array}{l}\text { first class check-in; } \\
\text { premium check-in }\end{array}$ & $\begin{array}{l}\text { first class check-in; check- } \\
\text { in at the first class termi- } \\
\text { nal in Frankfurt; premium } \\
\text { check-in }\end{array}$ \\
\hline & free baggage allowance & $\begin{array}{l}1 \text { additional bag in econ- } \\
\text { omy class, } 2 \text { bags in total } \\
\text { in premium economy class } \\
\text { and business class and } \\
3 \text { bags in first class }\end{array}$ & $\begin{array}{l}\text { an extra } 20 \text { kg; } 2 \text { bags } \\
\text { or } 3 \text { bags on certain } \\
\text { routes in economy class, } \\
3 \text { bags in premium } \\
\text { economy class and busi- } \\
\text { ness class, } 4 \text { bags in first } \\
\text { class }\end{array}$ & $\begin{array}{l}\text { an extra } 20 \mathrm{~kg} ; 2 \text { bags } \\
\text { or } 3 \text { bags on certain } \\
\text { routes in economy class, } \\
3 \text { bags in premium } \\
\text { economy class and busi- } \\
\text { ness class, } 4 \text { bags in first } \\
\text { class }\end{array}$ \\
\hline & $\begin{array}{l}\text { priority baggage } \\
\text { handling }\end{array}$ & no & yes & yes \\
\hline & lounge access & business lounge & $\begin{array}{l}\text { senator and star gold } \\
\text { lounges }\end{array}$ & $\begin{array}{l}\text { Lufthansa first class, Swiss } \\
\text { first and Austrian HON } \\
\text { circle lounge, first class } \\
\text { terminal in Frankfurt }\end{array}$ \\
\hline & $\begin{array}{l}\text { limousine and transfer } \\
\text { service }\end{array}$ & no & no & yes \\
\hline & exclusive service hotline & yes & yes & available worldwide $24 / 7$ \\
\hline
\end{tabular}

Note: Table contains information on elite membership levels only, entry level Miles \& More Member is excluded for methodological reasons.

Source: Based on austrian.com.

mobile practices of Czech and Slovak passengers as they illustrate, and even support, the uneven spatial accessibility of airline services. To be more precise, we mean that the hubs of network airlines which enable the entry to the world of frequent flyers are accessible in unlike quality and quantity from the metropolises, such as Prague and Vienna, as compared to other cities in the studied area.

Primarily, the programmes simply separate more mobile customers from the less mobile ones and ostentatiously acknowledge the former as mobile elites. The qualifying conditions which have to be fulfilled to reach a certain elite status in particular loyalty programmes are, however, based on very diverse mobile performances. To reach the second rank of membership, for instance, the airline customers have to undertake only 20 medium long flights ${ }^{7}$ to be assigned Silver status in Flying Blue programme yet, conversely, they need to perform a considerably higher mobility of 30 flights in Miles and More scheme to become Frequent Travellers. Executive Club occurs exactly in the middle as the

\footnotetext{
${ }^{7}$ Flights under 2 thousand miles.
} 
Table 4. Flying Blue: selected principles of FF programme as a way to diversify travel experience

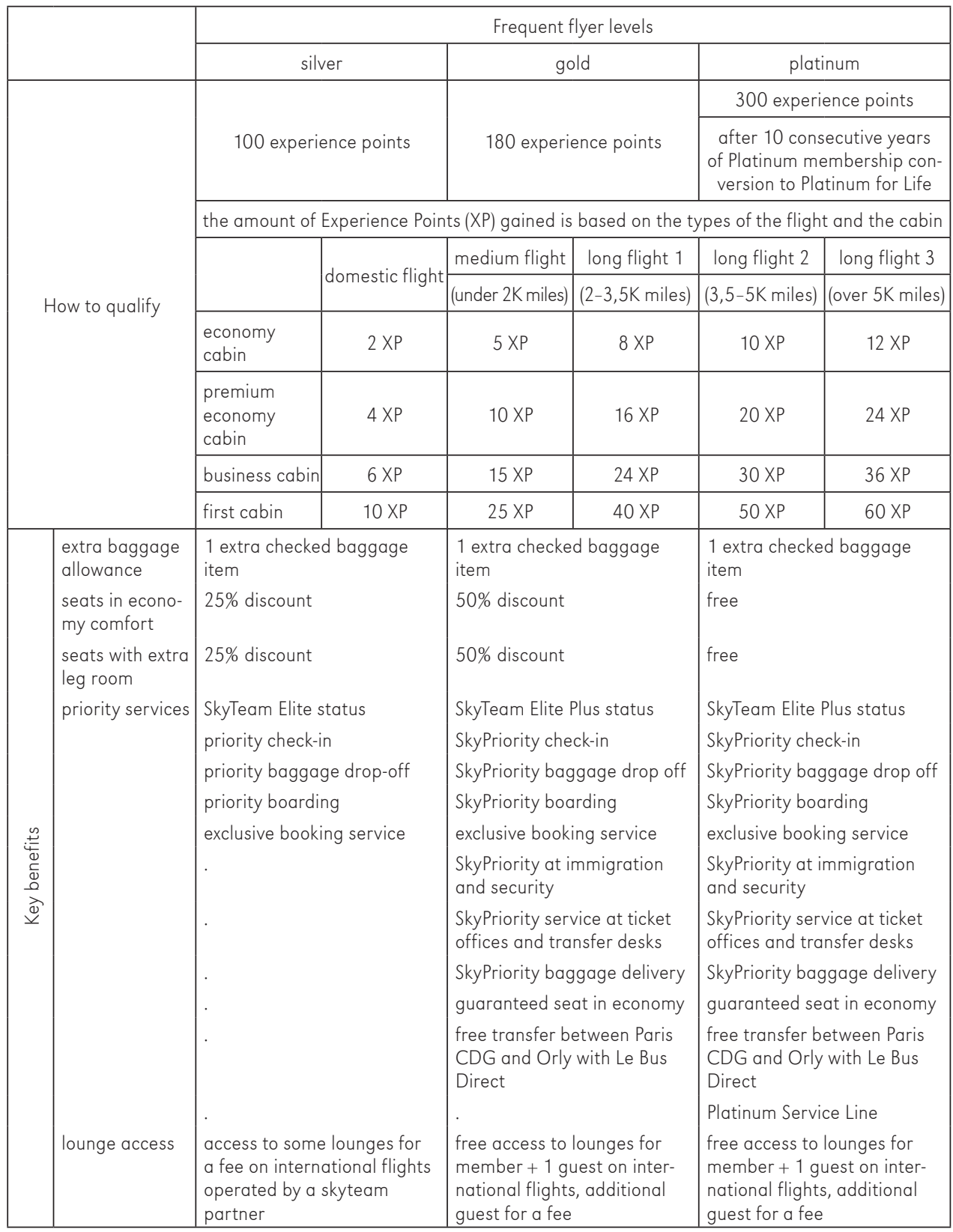

Note: Table contains information on elite membership levels only, entry level Explorer is excluded for methodological reasons.

Flying Blue FF programme contains also the level Petroleum except of levels Silver, Gold and Platinum. It is a special programme tailored to the needs of Flying Blue members working in oil, oil-related and gas industries and it has its specific conditions. It is, therefore, excluded from the table and analysis for methodological reasons.

Source: Based on klm.com. 
Table 5. Executive Club: selected principles of FF programme as a way to diversify travel experience

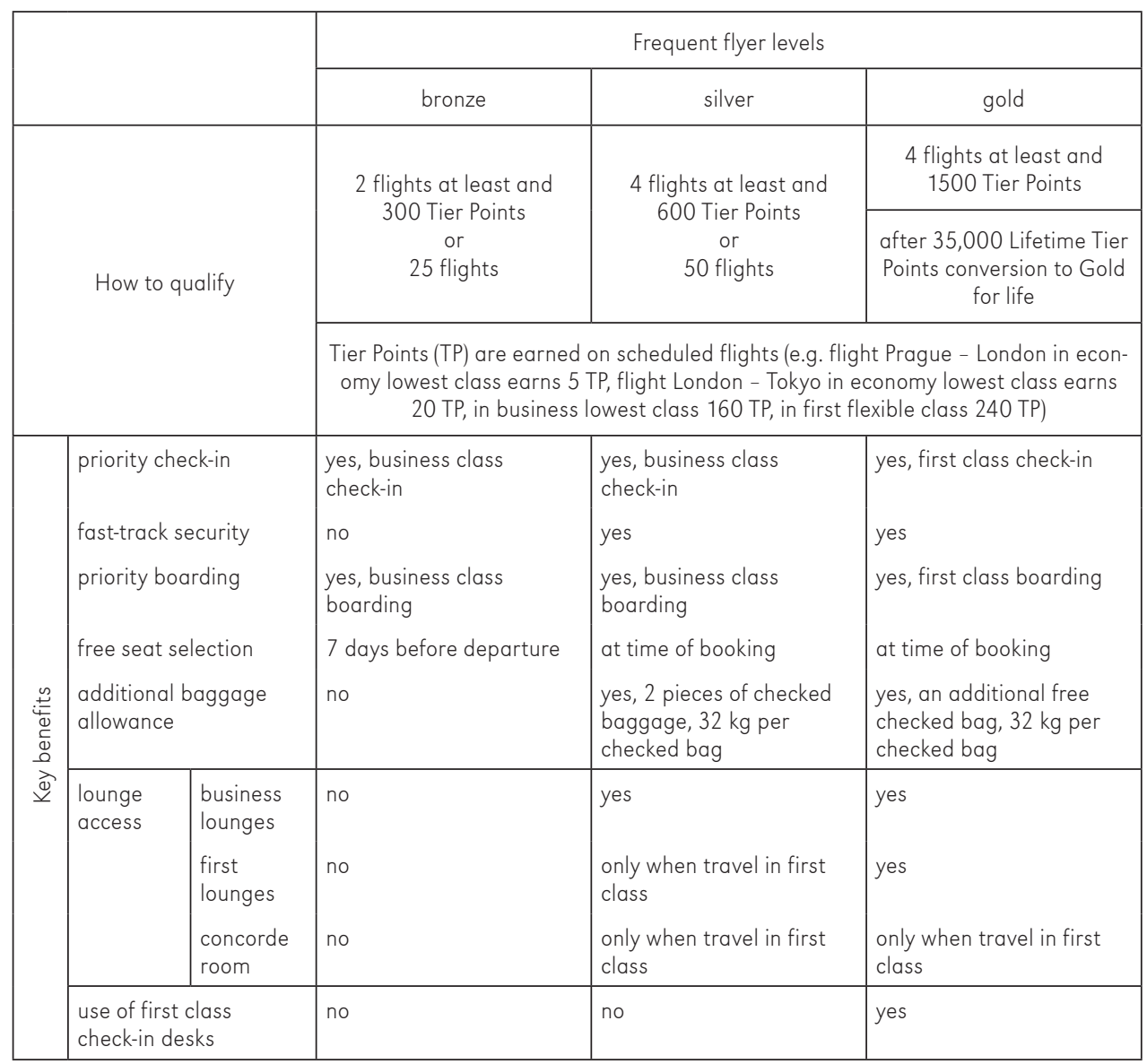

Note: Table contains information on elite membership levels only, entry level Blue is excluded for methodological reasons.

Source: Based on britishairways.com.

passengers need to conduct 25 flights to be rewarded with the Bronze status. Comparable differences are also to be found between other elite ranks in all examined programmes, nevertheless, we can conclude with certain level of generalisation that the difficulty needed to step up the hierarchy of elite passengers is much more pronounced in Miles and More scheme than in the Flying Blue and Executive Club programmes. The passenger gains the most prominent Platinum status in Flying Blue or Gold status in Executive Club programme after performing a similar number of business class flights between its European hubs and Tokyo (8.3 or 9.4 flights) but in the Miles and More counterpart this number of business class flights on the same route will still be sufficient to qualify only for the lowest elite level, the unadorned Frequent Traveller. To qualify for the HON Circle Member, the highest status in Miles and More, a traveller needs to undertake more than 50 business class flights between Frankfurt or Munich and Tokyo at least in two following calendar years. The demands placed on the regular passengers of Lufthansa, Austrian Airlines or LOT are thus significantly higher than on the KLM or British Airways passengers. 
The different qualifying conditions of selected frequent flyer programmes interestingly indicate the strategies of respective carriers to influence the social hierarchy of its elite passengers. Whereas the KLM's Flying Blue makes all its elite ranks accessible on the number of flights taken, the British Airlines' Executive Club excludes its Gold status solely for the members with sufficient amount of tier points, and the Miles and More program of Lufthansa Group only allows to qualify for the lowest Frequent Traveller status based on the flown flight segments, its most exclusive HON Circle is even only accessible for Business and First class passengers. To be labelled a frequent flyer, therefore, means something very different in terms and conditions of specific airlines. In order to maintain the exclusivity and elitism of its highest ranks, the airlines seem to carefully adapt the conditions of their loyalty programmes to geographic conditions of their major markets as they seek to cope with the travel behaviour of population in the regions they mainly serve.

Lufthansa as the main contributor and originator of the Miles and More programme transports much higher share of passengers on shorter domestic and European routes than KLM and British Airways which are used here as representatives of the Flying Blue and Executive Club schemes. The share of revenue-seat kilometres performed on domestic and European flights together amounts for $27.1 \%$ in the case of Lufthansa and only $18.2 \%$ in the case of KLM. The real difference between these figures is even bigger if we become aware of the fact that KLM combines revenue seat-kilometres from European and North African market into one broader geographic group (Lufthansa Group Annual Report 2017, KLM 2017 Annual Report). The geographic segmentation of total seat capacity offered on Lufthansa, KLM and British Airways flights is presented in Table 6 and these figures also clearly confirm that the share of domestic and European flights is significantly higher for Lufthansa. The exact number is $72.0 \%$ in the case of Lufthansa, $67.3 \%$ for KLM and only $63.0 \%$ for British Airways. The higher is the share of passengers on shorter flights of specific airlines, the more complicated is their access to higher ranks in respective frequent flyer programmes. As such, Lufthansa appears to have stronger impetus to prevent the access of regular and low profit passengers on shorter routes to the elite circles of loyalty schemes than KLM and British Airways. Interestingly then the majority of frequent flyer loyalty programmes evidently prefer passengers travelling less frequently to more distant destinations in higher cabin classes (thus in more expensive ways) than passengers

Table 6. Available seats (in \%) on flights to geographic market segments of principal European air carriers representing specific airline alliances: Lufthansa (Star Alliance), KLM (Sky Team) and British Airways (Oneworld)

\begin{tabular}{|l|c|c|c|}
\hline \multicolumn{1}{|c|}{ Flights } & Lufthansa & KLM & British Airways \\
\hline Domestic & 21.1 & 0.0 & 15.7 \\
Europe & 50.9 & 67.3 & 47.3 \\
$\quad$ Domestic + European flights & 72.0 & 67.3 & 63.0 \\
North Africa and Middle East & 4.7 & 2.8 & 6.0 \\
North America (US and Canada) & 8.1 & 7.6 & 14.8 \\
Asia & 7.7 & 8.3 & 7.4 \\
Rest of the world & 7.5 & 14.0 & 8.8 \\
\hline Total & 100.0 & 100.0 & 100.0 \\
\hline
\end{tabular}

Sources: Based on austrian.com, lufthansa.com, klm.com, britishairways.com, flightstats.com. 
who fly more frequently but on the shorter and less prominent commuter routes.

The diversity of Czech and Slovak frequent flyers is further enriched by the uneven accessibility of the hubs of network airlines and, respectively, of their frequent flyer programmes. The Czech Republic and Slovakia are spatially surrounded from north, west and south by the realms and hubs of airlines belonging to the very demanding Miles and More programme - LOT with its hub in Warsaw (Poland), Lufthansa with its hubs in Frankfurt and Munich (Germany) and Austrian Airlines with its hub in Vienna (Austria), all of them members of Star Alliance. All these hubs are geographically much closer to the Czech Republic and Slovakia, and, more importantly, they are much better connected to both countries by direct feeder flights than hubs in Amsterdam (Flying Blue) and London (Executive Club). Not only there are numerous direct flights from Vienna and
Prague but there are direct flights also from secondary airports, for instance there are 12 Lufthansa flights from Brno to Munich, 11 Austrian Airlines flights from Košice to Vienna or 8 LOT flights from Košice to Warsaw (see more details in Tab. 7). The accessibility of the Flying Blue and Executive Club is considerably lower with direct flight services to Amsterdam and London available only from Vienna and Prague (see again Tab. 7). Of course, the Flying Blue scheme is accessible also through the Czech Airlines as the member of Sky Team alliance, however, the supply of connecting flights of this carrier in Prague is very limited even within the scope of Europe. Therefore, for frequent flyers residing in the Czech Republic and Slovakia the geographic accessibility of Miles and More loyalty scheme is much better compared to Flying Blue and Executive Club, yet the very limited possibility to qualify for its elite membership further diminish the

Table 7. Geographic accessibility of FF programmes for FFs from the Czech Republic and Slovakia: flights during a week in October 2017 (2nd - 8th October)

\begin{tabular}{|c|c|c|c|c|c|c|c|c|c|c|c|}
\hline \multicolumn{2}{|c|}{$\begin{array}{l}\text { Flights } \\
\text { by hubbing } \\
\text { airline } \\
\text { to its hub }\end{array}$} & \multirow[t]{2}{*}{$\begin{array}{l}\text { FF pro- } \\
\text { gramme }\end{array}$} & \multicolumn{9}{|c|}{ Flights from } \\
\hline airline & hub & & PGR & BRQ & OSR & VIE & WAW & BTS & KSC & TAT & total \\
\hline OS & VIE & \multirow{4}{*}{$\begin{array}{l}\text { Miles } \\
\text { and } \\
\text { More }\end{array}$} & 32 & 0 & 0 & . & 18 & 0 & 11 & 0 & 61 \\
\hline LO & WAW & & 32 & 0 & 0 & 14 & . & 0 & 8 & 0 & 54 \\
\hline \multirow[t]{2}{*}{$\mathrm{LH}$} & FRA & & 34 & 0 & 0 & 42 & 28 & 0 & 0 & 0 & 104 \\
\hline & MUC & & 27 & 12 & 0 & 27 & 21 & 0 & 2 & 0 & 89 \\
\hline $\mathrm{KL}$ & AMS & \multirow{2}{*}{$\begin{array}{l}\text { Flying } \\
\text { Blue }\end{array}$} & 28 & 0 & 0 & 21 & 21 & 0 & 0 & 0 & 70 \\
\hline OK & PRG & & & 0 & 6 & 0 & 12 & 6 & 13 & 0 & 37 \\
\hline \multirow[t]{4}{*}{ BA } & LON & \multirow{4}{*}{$\begin{array}{l}\text { Execu- } \\
\text { tive } \\
\text { Club }\end{array}$} & 40 & 0 & 0 & 39 & 13 & 0 & 0 & 0 & 92 \\
\hline & $L H R$ & & 33 & 0 & 0 & 34 & 13 & 0 & 0 & 0 & 80 \\
\hline & $L G W$ & & 0 & 0 & 0 & 5 & 0 & 0 & 0 & 0 & 5 \\
\hline & $L C Y$ & & 7 & 0 & 0 & 0 & 0 & 0 & 0 & 0 & 7 \\
\hline
\end{tabular}

Notes: OS - Austrian Airlines, LO - LOT, LH - Lufthansa, KL - KLM, OK - Czech Airlines, BA - British Airways

VIE - Vienna, WAW - Warsaw, FRA - Frankfurt, MUC - Munich, AMS - Amsterdam, PRG - Prague, LON - London (total), LHR - London Heathrow, LGW - London Gatwick, LCY - London City, BRQ - Brno, OSR - Ostrava, BTS - Bratislava, KSC - Košice, TAT - Poprad/Tatry

Sources: Based on austrian.com, lufthansa.com, klm.com, britishairways.com. 
already disadvantaged regular air transport users in the studied area.

Naturally, different ranks of frequent flyers enjoyalso a different level ofelitetreatmentand their hierarchy is often spatially observable. Although there are some exclusive airport spaces they all have access to, such as priority check-in, priority boarding and some types of lounges, in a lot of other spaces they are obviously segregated. There are different lounges or specific lounge sections for different types of frequent flyers, they have uneven possibilities to upgrade to a higher cabin class and their seats on board of the airplanes often similarly correspond with their frequent flyer status moving the highest ranks further to the front and to the seats with more leg room. The micro-geography of passengers ranked differently in frequent flyer programmes varies significantly, they experience the spaces of airports and airplanes in differing ways as they move within aeromobile system in different speeds. Some of them move much smoother compared to the lower tiered passengers who have to overcome more spatial and temporal obstacles (e.g. less luxurious lounges or longer queues before check-in and boarding). In no aspect are the frequent flyers a homogenous group of elite passengers, on contrary, they embody an extraordinary internal diversity that is greatly produced and reproduced by the airlines themselves.

\section{Practices of frequent flyers}

To support the claim that elite aeromobilities might be far more diverse than traditionally assumed, we now present particular practices and existent spatial patterns of some of the frequent flyers from the Czech Republic and Slovakia. Our interviewees were all male and active professionals, two of them were based in Brno (Czech Republic) while the other three lived in Košice, Prešov and Bratislava (Slovakia) respectively. Their age ranged from 30 to almost 70 years with professions ranging from IT specialists to senior managerial and academic positions. They reported the membership ranks from the lowest silver
Frequent Traveller card with the Miles and More Star Alliance programme to the highest Platinum rank For Life with Flying Blue of the SkyTeam. Among our interviewees, notable differences became evident already on the schematic drawings of their aeromobile networks. While two of our interviewees travelled to various, often distant, destinations with only a few repeating routes and their aeromobile network spread out more-or-less globally, the other three were regular passengers on one or two fixed routes, mostly within one region, only occasionally flavoured by private flights to holiday destinations. In accordance with the expectations resulting from the flight data supply in section 1 of this paper, on one hand we have the frequent flyers with global networks (left scheme on Fig. 2), who recalled slightly more than 40 individual flights in the past year with worldwide destinations as well as many European cities. They described two or three more frequented routes related to their primary professional interests, the remaining destinations were places where they attended conferences or other meetings as well as holiday places whereas their location tend to be changing rather than repeating. On the other hand, we can recognize a different type of frequent flyers in our group, the commuters with regional networks. They greatly overrun the global frequent flyers in the sheer frequency of flights, yet their routes remain fixed within one region and rather limited to the connections between the place of their residence and their office abroad. On the right scheme on Figure 2 we see the aeromobile network of a weekly commuter from Košice (Slovakia) to Dusseldorf (Germany) who reported more than 160 individual flights in the past year, the other two commuters reported similar but less frequent flying on routes Košice - Vienna - London Heathrow and Vienna - London Heathrow.

As we suggested in the first section, an interesting disparity between both types of frequent flyers is to be noted on the airport types they use for their aeromobility. The global frequent flyers tend to drive to more 


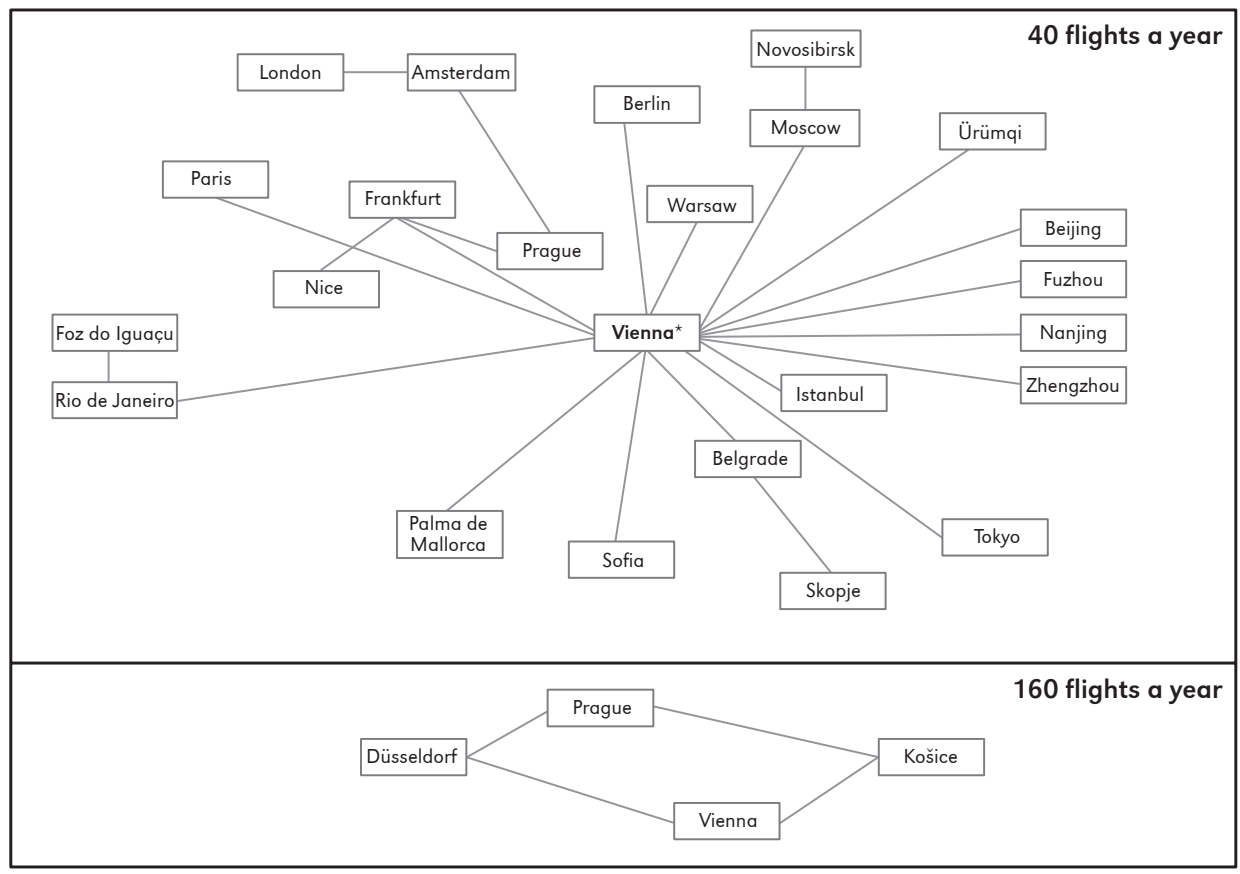

Figure 2. Aeromobile network of a global frequent flyer with around 40 flights a year and a commuter with more than 160 flights a year

Note: All of the interviewees rejected to sketch their aeromobile networks themselves, therefore the schemes were drawn by the authors following the spatial information provided by the interviewees during the interviewing process and under their direct supervision. All depicted accentuation was expressed by interviewees themselves and only reproduced by the authors in the drawings.

* The depicted accentuation of Vienna airport represents the strong preference expressed by the interviewee who frequently referred to the Vienna airport as his home-base.

distant but busier national hubs (Vienna and Prague), which are still, however, rather small in European comparison. They connect from these hubs to their final destinations mostly via higher ranked European hubs such as Frankfurt, Amsterdam or London. The frequency of regular flight services together with the good organisation of surface traffic around the airport have been mentioned as the key factors for choosing their departure airport. Therefore, Vienna Airport seems to be of strong strategic importance at least for the frequent flyers outside the Prague metropolitan region.

"Nowadays my basis is in Vienna. And why Vienna? Because I drive to Vienna mostly via
Bratislava which is longer but faster, I leave my car at Park and Drive Edberg. The third floor is the best because there is also the subway station. I buy a return ticket and I go 4 stops on subway to the airport. I usually fly alone and come back to the same place, so I can even use that return journey, it's perfect."

68-years old university professor, Brno (CZ), SkyTeam Platinum For Life

Whereas the excellent supporting infrastructure at Vienna Airport attracts the Czech and Slovak frequent flyers, the accessibility of Prague Airport has been rated far from ideal. In all our interviews it was articulated very clearly that the only option for 
frequent flyers to travel to an airport was by car as they value effectiveness and comfort of their travels above all. In this context, both interviewees based in Brno neglected Prague Airport mainly due to the problematic D1 highway connection with frequent maintenance disrupting their journeys. Another push factor seems to be the expensive parking directly at the airport in Prague with no suitable alternatives. Compared to Vienna, also the flight supply in Prague has been assessed as significantly lower (see Tab. 1). Therefore, if a suitable flight connection to their destination exists but operates only twice or three times a week, they cannot afford to wait for it and thus often opt for a departure from Vienna.

The commuters, however, strongly benefit from the extended network of regional airports, such as Košice and potentially Bratislava, Ostrava or Brno, from where they can easily and quickly fly with connecting flights of network airlines via smaller hubs (Vienna, Prague, Warsaw) to their end destination which is often another regional airport (see Tab. 2). One interesting exception seems to be the Bratislava region where the close vicinity of Vienna Airport attracts the commuters to travel slightly further to enjoy more frequent flight services to more prestigious airports such as London Heathrow as compared to London Stansted. These commuting frequent flyers admitted that without these regional flight services they will not be able to fulfil their job duties without being forced to change their residence. They do not require extended supporting infrastructure as they mainly reported to use company paid taxi services to travel to and from the airport and even the infrequency of flight services on their routes has not been viewed as problematic. As Salt (2009) noted, for the commuters, the journey itself is a part of their daily work regime, it is often a part of their contract, too. Therefore, the consequences of irregularities which they may experience have been commented on as inconvenient more for the company than for them as employees.
"I happened to me that I missed the flight to Košice. I wasn't thrilled, but I always try to see it as a positive thing. I missed a flight, so what? They gave me a hotel, they gave me dinner, they gave me luxurious breakfast, I didn't have to work next day (...). I only wrote to Germany that I am sorry, but I only fly now. I arrived home at 2 p.m. next day and I was smiling. And the airline even gave me 250 euro as a compensation."

30-years old data analyst, Prešov (SK), Miles and More Frequent Traveller card

The spatial patterns and strategies of all interviewed frequent flyers, in terms of their preferred routes, airports and carriers, to some extent always involved conscious planning to maximise the benefits of their elite status. Entering the "world of frequent flyers" and experiencing the benefits that the programmes offer to its elite members often meant a milestone in their air travel planning. Three of these benefits were described as particularly important - the lounge access, the enhanced speed of airport procedures such as check-in or security check and the extra baggage allowance. To make sure they will be able to use them on their journeys they all admitted active negotiations with the providers of their flight tickets being it their employer, a sponsor or a travel agency. As a result, whenever possible, they rather selected transfer flight of associated airline with a stop at the airport where they can use the lounge than a direct flight with an airline outside their programme. In this context, a very interesting disparity emerged from our interviews - the strong preference of Vienna Airport for both types of frequent flyers and at the same time the negative attitudes towards the Miles and More frequent flyer programme of Lufthansa Group. Both global frequent flyers among our interviewees were elite members of SkyTeam programmes (with KLM, Aeroflot and Czech Airlines as the most used carriers) and simultaneously accorded unsuccessful millage collection with Miles and More where they were not able to reach even the second 
silver rank of the frequent flyer membership. On the other hand, all commuters reported a Frequent Traveller status with Miles and More programme due to flying with Austrian Airlines, yet their rank was granted to them thanks to the high number of flight segments whereas the millage level remained rather low (see the qualifying criteria in Table 3 ). Only one interviewee, a senior contract auditor for an international ICT company, reached the Senator status with Miles and More which he admitted to have worked on intentionally by purchasing just enough business class tickets to qualify and thus ensure the privileged, fast and smooth transit in Vienna as well as quick de-boarding at London Heathrow. Without the pricy business class travel, the qualifying conditions were seen as unjust and extremely difficult to reach.

The uneasy access to the Miles and More elite membership which was reflected by our interviewees may, we believe, very well correspond with the argument we made in section 2 of this paper. The hierarchy of its frequent flyer ranks seems to be carefully adapted to the air travel patterns in their main area of interest. As such, the dividing line between the Frequent Traveller and the Senator status seems to represent also a qualitative shift from the regular customer towards the member of an elite circle. According to Thurlow and Jaworski (2006), the terminology of frequent flyer programmes aims to support the perception of upward social mobility thus the labels of their membership ranks gradually escalate the sense of exclusivity, luxury and elitism. In case of the Miles and More programme, this point applies by all means to the Senator and HON Circle labels, yet the second rank received a very simple name the Frequent Traveller. Interestingly, our interviews illustrate that this labelling seems to be very accurate in case of Czech and Slovak frequent flyers. Focusing on the small-scale spatiality of our interviewees within the airports and planes, it is strikingly evident how differently the two types of frequent flyers move, behave and express their perceived position within the hierarchy of airline passengers.
"Sometimes it infuriates me when I see that there are businessmen, people who evidently fly a lot and they are not able to prepare (for the security check). You know, they start to slowly put out their things into the trays to be X-rayed, they are checking their pockets, remembering what they have and where and so on. You need to wait for them because they are chatting or they are on the phone and then they hurry up. Well, I can do this in 20 seconds, even less, I don't need to show off."

$$
\begin{array}{r}
\text { 30-years old data analyst, } \\
\text { Prešov (SK), Miles and More Frequent } \\
\text { Traveller card }
\end{array}
$$

The speed and efficiency of the airport procedures and of the journey itself seem to be of a great value to the commuters whereas the global frequent flyers truly enjoy the cosmopolitism of airports and lounges, the recognition of their elite status and the extra comfort, time and treatment that comes with it. Except from lounges where there are spatially segregated sections for different ranks of frequent flyers, they also share many identical spaces at the airports and in the planes, yet they use them differently. In the quotation above a commuter comments on the smoothness of his passage thought the business class security check being often disrupted by the disorganised travellers. The very same process has been described from an opposite point of view by one of the global frequent flyers. He takes his time, enjoys the small talks with the airport staff as he feels entitled for the privilege of being approached individually and respectfully without being rushed. Similarly, all interviewees acknowledged the comfort of lounges in terms of being separated from the masses and hidden from the usual airport hustle. Yet, the global frequent flyers emphasised the variety of food and drinks, the perfect working conditions and, not at least, the possibility of being among the other high-class people that they can exchange ideas with, whereas the commuters valued comfortable chairs to relax, refresh, and charge their phones and reported 
to talk to no-one but other commuters. Perhaps the most obvious moments of mutual otherness have been demonstrated at the business class check-in counters and lounge receptions. Again, the global frequent flyers expressed the need to feel recognized and privileged, to have time for a little chit-chat with "the girls at the desk" and they admitted to be very demanding as customers. On the other hand, the commuters rarely demanded to be recognized as privileged as they seem not to feel to be a part of an elite, they simply desired to be recognized as regular customers who, for instance, do not wish to be constantly reminded of the way to their departure gate.

\section{Conclusion}

The idea of our paper is to draw attention to the considerable diversity of aeromobile practices among frequent flyers that are often wrongly and stereotypically perceived as a homogenous group of elite passengers. Although there are studies that examine the practices of coping with the frequent business travel (Lassen 2009), the different strategies of collecting bonus points to maintain the frequent flyer status (Gössling \& Nilsson 2009) or the stylisation of elites in the frequent flyer programmes (Thurlow \& Jaworski 2006), the internal hierarchy of its members related, moreover, with the spatiality of their practices, has been usually marginalized. We, therefore, aim to address this gap and to empirically contribute to the discussion on elite and non-elite mobilities from the Central European point of view.

In our case study we analysed three datasets that provide evidence of an existence of different types of frequent flyers in the Czech Republic and Slovakia and reveal their interesting mobile patterns. Firstly, we focused on the accessibility of flight connections that have deciding impact on the aeromobile strategies of frequent flyers living apart from the prominent European hubs. The extended network of regional airports cannot meet the needs of the globally active frequent flyers as the connectivity of global destinations remains still very limited. These global frequent flyers therefore use the local airports very rarely and instead work on their own strategies to effectively and comfortably reach the less prominent hubs in the region (Vienna and Prague) via ground transport. The supply of flight routes available for them in the less prominent hubs is namely much broader, yet still far behind the prominent European hubs (Amsterdam, Frankfurt, London), which also affects their spatial behaviour in terms of the higher rate of connection flights they must undertake. Nonetheless, another type of frequent flyers with entirely different spatial aeromobile patterns raises their numbers in the Czech Republic and Slovakia. As explained by Wickham and Vecchi (2010) and Salt (2010), these are mostly junior employees of international corporations that on contrary strongly benefit from the supply of regular flight services between small regional airports, which they use to commute frequently from the place of their residence to their offices abroad.

Secondly, we compared three most common frequent flyer programmes in the given area focusing on the internal hierarchy of their members, namely schemes Miles and More (Star Alliance), Flying Blue (Sky Team) and Executive Club (Oneworld). Frequent flyer programmes are remarkable instruments of social distinction, stylisation and elitism among airline passengers (Thurlow \& Jaworski 2006). With a closer look, the popular unifying figure of a frequent flyer suddenly becomes a complicated category with numerous possible ranks, names and privileges differed by the airline and the geography of its flight services. The most common hierarchy of frequent flyers into three distinctive ranks interestingly determines their access to several secluded VIP spaces whereas some of them they share (priority check-in, fast track) but in others they are strictly spatially differentiated (various lounges or distinctive sections of lounges, airplane seats). Moreover, setting the criteria to reach a certain status in frequent flyer programmes the 
airlines can actively influence the hierarchy of its frequent passengers and potentially exclude certain types of travellers from the highest ranks as evidenced by the exclusion of commuters from Senator and Hon Circle statuses in Miles and More scheme in this article. Finally and importantly, membership in a specific frequent flyer programme has a power to substantially influence the spatial strategies of individual passenger resulting in his choice of particular airline, departure and transit airport, flight, route etc. The Czech Republic and Slovakia are surrounded by the realm of Star Alliance airlines and thus, from a geographic point of view, their Miles and More programme is better accessible for local passengers than the other two schemes.

And lastly, we analysed the transcriptions of five semi-structured pilot interviews with frequent flyers from the Czech Republic and Slovakia to capture the first-hand descriptions of their aeromobile practices and spatial strategies. Here we encountered the global frequent flyers of the highest ranks that travel to various worldwide destinations, highly demanding of the privileges they feel to be entitled for as VIP passengers, especially on the plenitude of time, comfort, individuality and recognition of them as elite. On contrary, a very specific type of regional frequent flyers occurred in our interviews - the commuters that greatly overrun the

\section{References}

Adey P., Budd L., HubBard P., 2007. Flying lessons: Exploring the social and cultural geographies of global air travel. Progress in Human Geography, vol. 31, no. 6, pp. 773-791.

BirtChnell T., Caletrío J., (eds.), 2014. Elite mobilities. Abingdon: Routledge.

BOWEN J., 2010. The economic geography of air transportation: Space, time, and the freedom of the sky. London: Routledge.

BudD L., 2014. Aeromobile elites: Private business aviation and the global economy [in:] T. Birtch- global frequent flyers in the sheer frequency of flights but their routes remain fixed and are usually limited to the place of residence and the place of work often within one region. Despite the extraordinary frequency of their air travel, the regional frequent flyers commonly occupy the lowest ranks in the frequent flyer programmes and their self-identity rarely reflects any sights of elitism; instead of an elite treatment they prefer efficiency and speed and expect to be remembered as regulars that are familiar with the airport procedures. This case study thus demonstrates that the passengers' spatialities are too complex to be unequivocally summed up in terms of "miles" and loyalty programs and that speaking of more or less mobile passengers is often far from the colourful diversity of the world we live in and move within.

\section{Acknowledgements}

This paper was conceived while realizing the project "Spatial injustice of automobility technologies" (No. GA17-16097S), funded by the Czech Science Foundation.

Editors' note:

Unless otherwise stated, the sources of tables and figures are the authors', on the basis of their own research.

nell, J. Caletrío (eds.), Elite mobilities, Abingdon: Routledge.

Burghouwt G., 2007. Airline network development in Europe and its implications for airport planning. Aldershot: Ashgate.

Cresswell T., 2006. On the move: Mobility in the modern Western world. Routledge: Abingdon.

CWERner S., 2009a. Introducing aeromobilities [in:] S. Cwerner, S. Kesserling, J. Urry (eds.), Aeromobilities. London: Routledge, pp.1-21.

CWerner S., 2009b. Helipads, heliports and urban air space: governing the contested infrastructure of helicopter travel [in:] S. Cwerner, 
S. Kesserling, J. Urry (eds.), Aeromobilities, London: Routledge, pp. 225-246.

Derudder B., Devriendt L., Van Nuffel N., WitLOX F., 2010. Geographies of business air travel in Europe [in:] J.V. Beaverstock, B. Derudder, J. Faulcondbridge, F. Witlox (eds.), International business travel in the global economy, London: Ashgate, pp. 31-56.

Dobruszkes F., Lennert M., Van Hamme G., 2011. An analysis of the determinants of air traffic volume for European metropolitan areas. Journal of Transport Geography, vol. 19, no. 4, pp. 755-762.

ERDŐSI F., 2010. Closing up, keeping up or lagging behind? The fundamental problems and spatial differences of air transport in Eastern Europe. Discussion papers, no. 80. Pécs: Centre for Regional Studies of Hungarian Academy of Sciences.

GossLing S., Nilsson J.H., 2010. Frequent flyer programmes and the reproduction of aeromobility. Environment and Planning A, vol. 42, pp. 241-252.

GRENČíkOVÁ J., 2011. Vývoj a porovnanie štruktúry vybratých leteckých sietí Európy v období 20032009. [Dissertation thesis], Bratislava: Univerzita Komenského v Bratislave, Prírodovedecká fakulta.

Grenčíková J., KrižAn F., TolmáČl L., 2011. Stability and actuality of aviation networks in Bratislava and Prague. Moravian Geographical Reports, vol. 19, no. 1, pp. 17-31.

Higham J., Cohen S., Cavaliere C., 2014. Climate change, discretionary air travel and the "flyers' dilemma". Journal of Travel Research, vol. 53, no. 4, pp. 462-475.

Kellerman A., 2012. Daily spatial mobilities: Physical and virtual. Farnham: Ashgate.

Kraft S., Havlíková D., 2016. Anytime? Anywhere? The seasonality of flight offers in Central Europe. Moravian Geographical Reports, vol. 24, no. 4, pp. 26-37.

LASSEN C., 2009. A life in corridors [in:] S. Cwerner, S. Kesserling, J. Urry (eds.), Aeromobilities, London: Routledge, pp. 177-193.

LEE H-S., 2009. The networkability of cities in the international air passenger flows 19922004. Journal of Transport Geography, vol. 17, pp. 166-175.
Rodrigue J.P., Comtois C., Slack B., 2017. The geography of transport systems. London: Routledge.

SAlt J., 2010. Business travel and portfolios of mobility within global companies [in:] J.V. Beaverstock, B. Derudder, J. Faulconbridge, F. Witlox (eds.), International business travel in the global economy, Farnham: Ashgate, pp. 107-124.

SCHWANEN T., 2018. Geographies of transport III: New spatialities of knowledge production? Progress in Human Geography, vol. 42, no. 3, pp. 462-473.

Seidenglanz D., 2009. Competitivenes of air transport in Central Europe [in:] D. Wang, S.M. Li (eds.), Proceedings of the 14th HKSTS Internatinal Conference "Transportation and geography", Volume 2, Hong Kong: Hong Kong Society for Transportation Studies, pp. 483-492.

Strauss A., Corbin J., 1990. Basics of qualitative research: Grounded theory procedures and techniques. Thousand Oaks, CA, US: Sage Publications.

TAYLOR Z., 2016. Air charter leisure traffic and organised tourism in Poland: Are charters passé? Moravian Geographical Reports, vol. 24, no. 4, pp. 15-25.

ThuRLOW C., JAWORSKI A., 2006. The alchemy of the upwardly mobile: Symbolic capital and the stylisation of elites in frequent-flyer programmes. Discourse and Society, vol. 17, no. 1, pp. 473-486.

URRY J., 2009. Aeromobilities and the global [in:] S. Cwerner, S. Kesserling, J. Urry (eds.), Aeromobilities, London: Routledge, pp. 25-38.

Wickham J., Vecchl A., 2010. Hierarchies in the air: Varieties of business air travel [in:] J.V. Beaverstock, B. Derudder, J. Faulconbridge, F. Witlox (eds.), International business travel in the global economy, Farnham: Ashgate, pp. 125-143.

\section{Other sources:}

KLM 2017 AnnuAL RePORT, https://www.klm. com/corporate/en/images/KLM_Annual_ Report_2017_tcm729-1029524.pdf [11 June 2019]. 
Lufthansa Group Annual Report 2017, https:// investor-relations.lufthansagroup.com/fileadmin/downloads/en/financial-reports/annualreports/LH-AR-2017-e.pdf [11 June 2019].

OAG Aviation Worldwide, https://www.oag.com https://www.flightstats.com/v2/ https://www.austrian.com

https://www.klm.com

https://www.britishairways.com

https://www.lufthansa.com
(C) Veronika Zuskáčová - Daniel Seidenglanz

(C) Geographia Polonica

(C) Institute of Geography and Spatial Organization

Polish Academy of Sciences • Warsaw • 2019
Article first received • June 2018

Article accepted - May 2019

Open acces article under the CC BY 4.0 license 